\title{
MARINE TURTLE BONES FROM AN ARCHAEOLOGICAL SITE IN POLYNESIA YIELD RELIABLE AGE DETERMINATIONS
}

\author{
T S DYE
}

\author{
Hawaii Pacific College, Honolulu, Hawaii 96813
}

\begin{abstract}
Accelerator mass spectrometry dating of three $50 \mathrm{~g}$ samples of marine turtle bone from the basal cultural stratum of the Tongoleleka archaeological site, Lifuka Island, Kingdom of Tonga, South Pacific yields results that agree with conventional ${ }^{14} \mathrm{C}$ dates on marine shell. A method for calibrating these dates that takes into account the long distance migrations of marine turtles in the South Pacific is proposed. A sample size greater than $50 \mathrm{~g}$ is recommended for routine AMS dating of marine turtle bone.
\end{abstract}

Wood charcoal samples of sufficient size for routine radiocarbon dating are rare in the oldest cultural layers of most archaeological sites in Polynesia. Routine accelerator mass spectrometry (AMS) dating of bone proteins gives archaeologists an important new source of datable materials (James et al 1987; Gillespie, Hedges \& Humm 1986; Stafford et al, in press), since many early Polynesian sites contain abundant bones of animals eaten by colonists (Dye \& Steadman, in press). This paper describes the results of AMS dating of marine turtle bones from an early archaeological site in the Kingdom of Tonga. It also provides data on the minimum sample size for routine AMS dating of marine turtle bone samples and proposes a procedure for calibrating age estimates from marine turtle bone collected at archaeological sites in the South Pacific.

Marine turtle bones were collected from the basal cultural stratum of the Tongoleleka site on Lifuka Island $\left(19^{\circ} 49^{\prime} \mathrm{S}, 174^{\circ} 25^{\prime} \mathrm{W}\right)$ in the Ha'apai Group, Kingdom of Tonga. The basal cultural stratum of the Tongoleleka site represents the initial occupation of a sand dune located along a prograding shoreline by a people who manufactured a distinctive dentate-stamped earthenware (Dye 1988). On stylistic and technologic grounds, this earthenware can be classified as Early Eastern Lapita pottery (Green 1979), which differs from succeeding pottery styles by the large areas of the pot that were decorated, the complexity of the dentate-stamped decoration, and the diverse vessel forms that were produced. Previous studies indicate that the makers of Early Eastern Lapita pottery were the initial settlers of Tonga (see Bellwood 1979; Davidson 1979; Kirch 1984). A recent evaluation of the settlement period ${ }^{14} \mathrm{C}$ age estimates concludes that the Lapita potters settled the Tongan Islands in the 9th century BC (Poulsen 1987). The age of the Tongoleleka site is of further interest because the bones of five species of extinct birds (Steadman 1989) and an extinct iguana (Pregill \& Dye 1989) were recovered from the basal cultural stratum there.

The three 50g samples reported here (AA-1920, -1921, -1923) each represent the postcranial remains of one or more individuals of one or more unidentified marine turtle genera. Based on modern estimates of marine turtle population sizes in Tonga (Pritchard 1982), the bones are most likely those of the green turtle (Chelonia mydas) or the hawksbill turtle (Eretmochelys imbricata). The samples were selected from stratigraphically secure contexts associated with Early Eastern Lapita pottery, other artifacts and abundant food remains, including the bones of extinct birds and iguanas. A marine turtle bone concentration index of $414 \mathrm{~g} / \mathrm{m}^{3}$ of excavated deposit in the basal cultural stratum of the Tongoleleka site contrasts strongly with the lack of marine turtle bone in the underlying, presettlement stratum. It is unlikely that the bones derived from some older, natural deposit. Similarly, a decline in the amount of marine turtle bone in the middle strata $\left(22-146 \mathrm{~g} / \mathrm{m}^{3}\right)$ and upper stratum $\left(17 \mathrm{~g} / \mathrm{m}^{3}\right)$ of the site diminishes the possibility that the analyzed bones were introduced into the basal cultural stratum from younger cultural deposits. There is thus every indication that the analyzed marine turtle bones are contemporaneous with the cultural materials in the basal cultural stratum of the site. 
${ }^{14} \mathrm{C}$ measurements were made by the NSF-Arizona Accelerator Facility for Radioisotope Analysis, following procedures described by Gillespie, Hedges \& Humm (1986) for preparation of the bone samples. Sample AA-1920 yielded insufficient carbon for routine analysis and was diluted 2:1 with ${ }^{12} \mathrm{CO}_{2}$. A fourth sample (AA-1922) yielded only $0.044 \% \mathrm{~N}$ and could not be analyzed. Thus, samples larger than 50g are recommended for routine AMS dating of marine turtle bone from early Polynesian archaeological sites.

The choice of a calibration curve is dictated by the diets of marine turtles. The omnivorous diets of both green (mainly herbivorous) and hawksbill turtles are dominated by plants and animals found in shallow water marine ecosystems (Mortimer 1982; Bjorndal 1985). Studies of stable carbon isotopes in these ecosystems indicate that the primary source of organic carbon is the reef benthos, and that detritus derived from land contributes a negligible amount of carbon (Smith, Schneider \& Tribble 1985). The $\delta^{13} \mathrm{C}$ values of -17.9 for samples AA-1921 and -1923 fall at the light end of the range of $\delta^{13} \mathrm{C}$ values determined from sediments derived from coral reefs and sea grasses, but are heavier than sediments with a terrigenous component (Smith, Schneider \& Tribble 1985: 446). The $\delta^{13} \mathrm{C}$ value for sample AA-1920 was not estimated in the laboratory, but is assumed to be the same as the other two samples. Thus, with the aid of the computer program CALIB (Stuiver \& Reimer 1986), the age estimates were calibrated using the marine model of Stuiver, Pearson \& Braziunas (1986).

The geographic range of marine turtle migrations complicates the selection of an appropriate correction factor $(\Delta \mathrm{R})$ for the marine model. Tag and recapture studies indicate that individual green turtles in the South Pacific range over $4500 \mathrm{~km}$ from the Society Islands to Vanuatu (Meylan 1982). Less is known of the range of hawksbill turtles, although evidence suggests that they migrate long distances as well (Meylan 1982: 96). Green turtles in the South Pacific appear to be isolated from populations in the North Pacific (Balazs 1982). These long distance migrations mean that marine turtles ingest carbon from a wide range of local marine environments in the South Pacific, each of which is likely to differ in its own way from the marine model of Stuiver, Pearson \& Braziunas (1986). To date, a single $\Delta \mathrm{R}$ estimate from a South Pacific island group in the green turtle's range, $45 \pm 30$ from the Society Islands (Stuiver, Pearson \& Braziunas 1986), is available, and this has been applied. As more $\Delta \mathrm{R}$ estimates for the South Pacific become available, an average of these values would perhaps more closely model the carbon intake of marine turtles.

The reliability of age estimates from marine turtle bone may be assessed by comparing them with age estimates from other materials associated with Early Eastern Lapita pottery. Two stratigraphically secure samples of marine shells (ANU-541 and NZ-727) from Tongatapu (Poulsen 1987: Table 32), the nearest island with comparable dated cultural remains, provide the best basis for comparison. According to Poulsen's (1987: 78-80) detailed stratigraphic analyses, these are the only ${ }^{14} \mathrm{C}$ samples from Tongatapu that can be confidently associated with dentate-stamped pottery similar to that recovered from the basal stratum of the Tongoleleka site. Figure 1 compares the $1 \sigma$ and $2 \sigma$ age ranges of the Tongoleleka marine turtle samples with age estimates from the two Tongatapu marine shell samples. Samples AA-1921 and -1923 fit well with the Tongatapu age estimates, overlapping at $1 \sigma$. Sample AA-1920, which was diluted with ${ }^{12} \mathrm{CO}_{2}$, appears to be older than the other samples.

Two hypotheses could explain the discrepancy between the age of sample AA-1920 and the other two turtle bone samples. The first is that the age estimate for sample AA-1920 is a statistical outlier, and that the actual age of the sample is younger than the estimate by ca $3 \sigma$. The second is that sample AA-1920 actually dates an early portion of the Lapita period in the region, and that the three turtle bone samples together accurately estimate the duration of the Early Eastern Lapita period in Tonga. This second hypothesis receives apparent support from one ${ }^{14} \mathrm{C}$ date (NZ-726) 
NZ-727

ANU-541

AA-1923

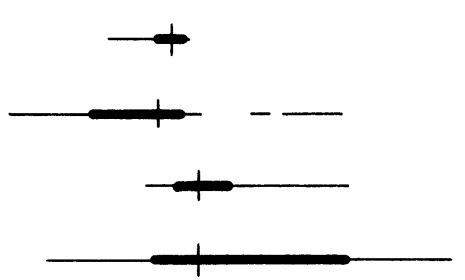

AA-1921

$A A-1920$

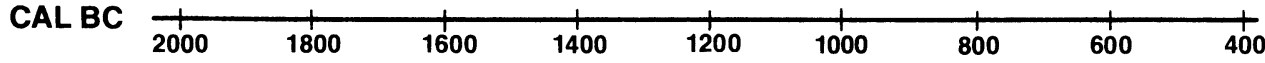

Fig 1. Calibrated age ranges $(-=1 \sigma ;-=2 \sigma)$ and intercepts $(\mid)$ of marine turtle bone samples from Tongoleleka compared with calibrated age ranges $(1 \& 2 \sigma)$ and intercepts of marine shell samples (ANU-541, NZ-727) from Lapita period archaeological sites on Tongatapu Island, Kingdom of Tonga (Poulsen 1987: Table 32). The Tongoleleka samples are corrected with the calibration curve of Stuiver, Pearson \& Braziunas (1986). The Tongatapu shell samples, corrected for oceanic reservoir effect by Polach (1987), are calibrated with the curve of Pearson and Stuiver (1986). Note that samples AA-1921 and -1923 overlap the two marine shell samples at $1 \sigma$.

from Tongatapu with a calibrated $1 \sigma$ age range of 1495-1370 BC (Poulsen 1987, Table 32) and two (I-10632 and -10633) from Niuatoputapu, a small island at the northern end of Tonga (Kirch 1988: 140). The two Niuatoputapu samples yielded calibrated 1o age ranges of 1735-1508 BC and 1530$1373 \mathrm{BC}$, respectively. There are reasons to question whether these three samples actually date Early Eastern Lapita culture in Tonga, however. NZ-726 was recovered in a disturbed context and has not been accepted by prehistorians (Groube 1971: 302; Green 1979: 33; Kirch 1984: 50; Poulsen 1987: 79). Both of the Niuatoputapu samples are from giant clam (Tridacna sp) shells that were presumably taken from the lagoon where groundwater discharge through the uplifted limestones and unconsolidated calcareous sands adjacent to the lagoon (Kirch 1988: 21-23) may have introduced significant amounts of old carbon into the marine environment. Two charcoal samples from the same stratum of site NT-90 (Kirch 1988: 140) yielded corrected $2 \sigma$ age ranges of $155 \mathrm{BC}-\mathrm{AD} 460$ (I-9934) and $\mathrm{AD}$ 650-1135 (I-10481), both significantly younger than the Tridacna shell samples. Thus, there is insufficient evidence with which to discriminate between the two hypotheses. The duration of the Lapita period in Tonga will be reliably estimated, and anomalous dates identified, only after additional stratigraphically secure samples from the region are collected and dated. Ottaway (1973) describes a suitable technique for estimating the duration of cultural periods with ${ }^{14} \mathrm{C}$ dates.

AMS dating of ca 2800 -yr-old marine turtle bones from a Lapita period archaeological site yields results that agree with conventional ${ }^{14} \mathrm{C}$ ages from marine shells recovered from similar cultural contexts. The suggestion that marine turtle bone is a suitable material for AMS dating will be strengthened if comparable ages can be obtained from stratigraphically associated marine turtle bone and marine shell or charcoal from the same site. 


\section{ARCHAEOLOGIC SAMPLES}

\section{Lifuka Island series}

\section{AA-1920. Lifuka Island}

$$
\begin{array}{r}
3660 \pm 190 \\
\text { Est } \delta^{13} C=-17.9 \% \text { o }
\end{array}
$$

Marine turtle bone from Tongoleleka site, Unit ONOW, Layer IV; assoc with Lapita pottery and bones of extinct birds and iguanas. Comment: cal 1790 (1543) $1360 \mathrm{BC}$ at 1\%; cal 3739 (3492) $3309 \mathrm{BP}$ at $1 \sigma$.

\section{AA-1921. Lifuka Island}

$2960 \pm 120$

$\delta^{13} \mathrm{C}=-17.9 \%$

Marine turtle bone from Tongoleleka site, Unit 45N1W, Layer IV; assoc with Lapita pottery and bones of extinct birds and iguanas. Comment: cal 830 (763) $540 \mathrm{BC}$ at $1 \sigma$; cal 2779 (2712) 2489 BP at 10.

\section{AA-1923. Lifuka Island}

$2960 \pm 60$

$\delta^{13} \mathrm{C}=-17.9 \%$

Marine turtle bone from Tongoleleka site, Unit ONOW, Layer IV; assoc with Lapita pottery and bones of extinct birds and iguanas. Comment: cal 797 (763) $720 \mathrm{BC}$ at $1 \sigma$; cal 2746 (2712) $2669 \mathrm{BP}$ at $1 \sigma$.

\section{ACKNOWLEDGMENTS}

Fieldwork in Tonga was supported by National Science Foundation Grant BNS 83-14005. Funds for AMS dating were provided by National Science Foundation Grant BSR-8607535 awarded to D W Steadman, New York State Museum. Permission to carry out research in Tonga was graciously granted by the Government of H M King Tāufa'āhau Tupou IV. K Turekian, Yale University suggested AMS dating of marine turtle bones from the Tongoleleka site.

\section{REFERENCES}

Balazs, GH 1982 Status of sea turtles in the central Pacific Ocean. In Bjorndal, KA, ed, Biology and conservation of sea turtles. Washington DC, Smithsonian Inst Press: 243-252.

Bellwood, P 1979 Man's conquest of the Pacific. New York, Oxford Univ Press.

Bjorndal, KA 1985 Nutritional ecology of sea turtles. Copeia 1985: 736-751.

Davidson, J 1979 Samoa and Tonga. In Jennings, J D, ed, The prehistory of Polynesia. Cambridge, Massachusetts, Harvard Univ Press: 82-109.

Dye, TS, (ms) 1988 Social and cultural change in the prehistory of the ancestral Polynesian homeland. PhD dissert, Yale Univ, New Haven.

Dye, TS and Steadman, DW, in press, The human settlement of Polynesia and its effects on island faunas. American Scientist.

Gillespie, R, Hedges, REM and Humm, MJ 1986 Routine AMS dating of bone and shell proteins. In Stuiver, M and Kra, RS, eds, Internatl ${ }^{14} \mathrm{C}$ conf, 12th, Proc. Radiocarbon 28(2A): 451-456.

Green, RC 1979 Lapita. In Jennings, JD, ed, The prehistory of Polynesia. Cambridge, Massachusetts, Harvard Univ Press: 27-60.

Groube, LM 1971 Tonga, Lapita pottery, and Polynesian origins. Jour Polynesian Soc 80: 278-316. 
James, HF, Stafford, TW, Steadman, DW, Olson, SL, Martin, PS, Jull, AJT and McCoy, PC 1987 Radiocarbon dates on bones of extinct birds from Hawaii. Natl Acad Sci USA Proc 84: 2350-2354.

Kirch, PV 1984 The evolution of the Polynesian chiefdoms. Cambridge, Cambridge Univ Press.

1988 Niuatoputapu: The prehistory of a Polynesian chiefdom. Thomas Burke Memorial Washington State Mus Mono

5. Seattle, Burke Museum.

Meylan, A 1982 Sea turtle migration: evidence from tag returns. In Bjorndal, KA, ed, Biology and conservation of sea turtles. Washington DC, Smithsonian Inst Press: 91-100.

Mortimer, JA 1982 Feeding ecology of sea turtles. In Bjorndal, KA, ed, Biology and conservation of sea turtles. Washington DC, Smithsonian Inst Press: 103-109.

Ottaway, BS 1973 Dispersion diagrams: A new approach to the display of carbon-14 dates. Archaeometry 15: 5-12.

Pearson, GW and Stuiver, M 1986 High-precision calibration of the radiocarbon time scale, 500-2500 BC. In Stuiver, M and Kra, RS, eds, Internatl ${ }^{14} \mathrm{C}$ conf, 12th, Proc. Radiocarbon 28(2B): 839-862.

Polach, HA 1987 The interpretation and comparison of the radiocarbon results. In Poulsen, J, Early Tongan prehistory. Terra Australis 12, Canberra, Australian Natl Univ: 270-273.

Poulsen, J 1987 Early Tongan prehistory. Terra Australis 12, Canberra, Australian Natl Univ.

Pregill, GK and Dye, T 1989 Prehistoric extinction of giant iguanas in Tonga. Copeia 1989(2): 505-508.

Pritchard, PCH 1982 Marine turtles of the South Pacific. In Bjorndal, KA, ed, Biology and conservation of sea turtles. Washington DC, Smithsonian Inst Press: 253-262.

Smith, SV, Schneider, RC and Tribble, GW 1985 Carbon isotopic balance in coral reef ecosystems. Internatl coral reef cong, 5th, Proc. Tahiti 3, Mo'orea, Fr Polynesia, Antenne Mus-EPHE: 445-450.

Stafford, TW Jr, Hare, PE, Currie, L, Jull, AJT and Donahue, D, in press, Accelerator ${ }^{14} \mathrm{C}$ dating at the molecular level. Jour Archaeol Sci.

Steadman, DW 1989 New species and records of birds (Aves: Megapodiidae, Columbidae) from an archaeological site on Lifuka, Tonga. Biol Soc Washington Proc 102(3): 537-552.

Stuiver, M, Pearson, GW and Braziunas, T 1986 Radiocarbon age calibration of marine samples back to 9000 cal yr BP. In Stuiver, $\mathrm{M}$ and $\mathrm{Kra}, \mathrm{RS}$, eds, Internatl ${ }^{14} \mathrm{C}$ conf, 12th, Proc. Radiocarbon 28(2B): 980-1021.

Stuiver, M and Reimer, PJ 1986 A computer program for radiocarbon age calibration. In Stuiver, M and Kra, RS, eds, Internatl ${ }^{14} \mathrm{C}$ conf, 12th, Proc. Radiocarbon 28(2B): 1022-1030. 